\title{
PREVALENCE AND SEVERITY OF PTERYGIUM AMONG COMMER- CIAL MOTORCYCLE RIDERS IN SOUTH EASTERN NIGERIA
}

\author{
E.O ACHIGBU ${ }^{1}$ and U. F. EZEPUE ${ }^{2}$ \\ ${ }^{1}$ Department of Ophthalmology, Federal medical Centre, Owerri, Imo State, Department of Ophthalmology, \\ University of Nigeria Teaching Hospital, Enugu, Enugu state
}

DOI: http://dx.doi.org/10.4314/gmj.v48i3.7

Corresponding Author

Email: bebediora@yahoo.com

Conflict of Interest: None declared

\section{SUMMARY}

Background: Pterygium is common among outdoor workers who are daily exposed to sunlight and dust due to repeated conjunctival /corneal drying and microtrauma especially in the tropics. Commercial motorcyclists in Nigeria are outdoor workers who spend the greater part of the day outdoors under the intense heat and dust characteristic of this part of the world and would therefore be largely predisposed to developing this conjunctival disorder.

Objective: The aim of this study is to determine the prevalence and severity of pterygium among these workers and relate these findings to their duration of work.

Methods: A cross sectional study with a multi stage random sampling design was used to choose the 615 subjects enrolled in the study.

Results: The prevalence for pterygium was $19.3 \%$ (206 eyes) with stage 1 occurring mostly (52\%) followed by stage 2(46\%). Pterygium was common among riders who had been riding for 5 years or less. The relationship between duration of riding and pterygium severity was significant $(p=0.009)$. This prevalence was unaffected by the use of regular sun glasses $(p=0.188)$.

Conclusion: A strong relationship exists between commercial motorcycle riding and development of pterygium not affected by using regular sunglasses. We recommend that helmets with full face shields and/or proper UV protected riding goggles where the helmets have no face shield be enforced by the regulation bodies so as to reduce the prevalence of these disorders.

Keywords: Pterygium, Prevalence, Commercial motorcyclists, work duration.

\section{INTRODUCTION}

Pterygium has a worldwide distribution though it is considered more common in warm, dry climates ${ }^{1}$ with a reported prevalence as high as $22 \%$ in equatorial areas and less than $2 \%$ in latitudes above 40 degrees. $^{2}$
It is speculated to be associated with corneal and conjunctival microtrauma from exposure to sunlight and/or dust $^{3}$. The exposure to UV light is thought to cause repeated rapid evaporation and destruction of the tear film with subsequent elastoid degeneration of the sub epithelial connective tissue. ${ }^{4,5}$

A number of risk factors have been identified for the development of pterygium. In a large case control study in Australia ${ }^{6}$, a 4.1 fold greater relative risk of pterygium development was found for persons living in the tropics (less than $30^{\circ}$ latitude), 11 fold for those working in a sandy, outdoor environment, 9-fold for subjects without a history of wearing spectacles or sunglasses and 2-fold for those who never wear a hat. Taylor et $\mathrm{al}^{7}$ also found a statistically significant relationship between ultraviolet light (UV-A and UV-B) and the development of pterygium in a large group of fishermen.

In another study, workers exposed to dusty indoor environment had higher prevalence of pterygium than those who experienced higher levels of outdoor ultraviolet radiation. ${ }^{8}$ In other studies carried out in Nigeria ${ }^{9}$ and South India ${ }^{10}$ higher prevalence of pterygium was recorded among the outdoor workers than the indoor workers. These studies and more have essentially shown that the development of pterygium is significantly associated with exposure to sunlight or sand.

Commercial motorcyclists are outdoor workers who are daily exposed to sunlight, wind, and dust in the course of carrying out their regular duties especially in the dusty coal city of Enugu state, south eastern Nigeria. This study therefore aims to determine the prevalence and severity of pterygium in these motorcyclists and also find out if their prevalence is influenced by how long they have been working as commercial motorcyclists. 


\section{SUBJECTS AND METHOD}

\section{Study Setting}

The location of study is Enugu, capital of Enugu State, Nigeria. Enugu State lies between latitude $5^{0} 56^{\prime} \mathrm{N}$ and $7^{0} 06^{\prime} \mathrm{N}$ and longitude $6^{0} 53^{\prime} \mathrm{E}$ and $7^{0} 55^{\prime} \mathrm{E}$. It occupies a land area of about $802,295 \mathrm{~km}^{2}$ and located at an altitude of 218.7 metres above sea level with a yearly temperature between $19.5-34.5^{\circ} \mathrm{C}$, a humidity range between $42-48 \%$ in wet and dry seasons respectively, and an annual rainfall of $200 \mathrm{~cm}$. Enugu metropolis is essentially urban and comprises three local government areas namely Enugu East, Enugu North, and Enugu South. Coal is the most abundant natural resource.

\section{Study Definitions}

Pterygium is a triangular sheet of fibro vascular tissue which is adherent to the underlying tissue and gradually encroaches onto the cornea. ${ }^{11}$ It has a base and an apex. The severity of pterygium was graded grossly based on its apical extent because there was no slit lamp available for more detailed assessment. It is stage 1 if the apex is at or before the limbus, stage 2 if it's between the limbus and the pupillary margin, stage 3 , if it's at the pupillary margin and stage 4 if it has extended beyond the pupillary margin (pterygium blindness).

\section{Study Population}

The 615 motorcyclists included in the study were all officially registered as professional commercial motorcyclists, willingly consented to answer our questions, and undergo ocular examinations. All the motorcyclists who did not fulfil the above criteria were excluded from the study.

\section{Study Design}

This was a cross-sectional survey with a multi-stage random sampling design in which 615 commercial motorcyclists from 14 units were selected from a sample frame of 60 passenger pick up points (units) in Enugu metropolis.

The minimum sample size representative of the study population was determined using the formula for a study population $<10,000$ people. $^{12}$

The calculated minimum sample size was 146. An additional $10 \%$ allowance for possible attrition was made giving a minimum sample size of 161 . However, a total of 615 motorcyclists were enrolled from the 14 units which were selected by simple random sampling from the 60 motorcycle assembly units in the three local government areas in Enugu metropolis. Only the motorcyclists present at the time of the study in each of these units were enrolled and ticked off with their register. No second visit was made to any unit. The entire survey lasted eight weeks.

\section{Ethical Consideration}

Ethical clearance was obtained in writing from the University of Nigeria Teaching Hospital, Enugu Ethics committee. Informed verbal consent was also obtained from the leaders of each unit, and each subject who participated in the study after the details of the study was explained to them. Subjects with eye conditions requiring further care such as bacterial conjunctivitis, inflamed pterygium, stage 2 pterygium and above, glaucoma, cataract, refractive errors were referred to the eye clinic of the University of Nigeria Teaching Hospital, Enugu for further management. The subjects were also counselled on the need to protect their eyes while riding.

\section{Data Collection}

Relevant data was obtained using a structured questionnaire. The questionnaire served to elicit information such as the bio-data, riding history and ocular history while a protocol form was used for recording findings on ocular examination. The ocular examination was carried out under any available decent shade at the motorcycle assembly points. Visual acuity (unaided, aided and with pin hole) was assessed using Snellen's literate and illiterate (E) charts at 6 metres by the assistants who are resident doctors. The anterior segment of the eyes was examined using a pen torch while the posterior segment was examined with Welch Allyn direct ophthalmoscope by the researcher. The questionnaires were administered by the researcher and assistants in clear language.

\section{Data Analysis}

Data was analysed using SPSS version 11.5. The chisquare was used to cross tabulate the various variables for meaningful interpretations. A p-value of less than 0.05 was considered significant.

\section{RESULTS}

A total of 615 commercial motorcycle riders were examined from 14 motorcycle assembly units in Enugu Metropolis. The mean age was 38.1 years $+/-10.27$.

The commonest ocular findings were conjunctival disorders. Pingueculum was found in 269 eyes $(25.3 \%)$ followed closely by pterygium in 206(19.3\%) eyes and hyperaemia and sub conjunctival haemorrhage in $160(15.0 \%)$ eyes.

One hundred and seven (107) eyes (52.0\%) had stage 1 pterygium, 95 eyes $(46.0 \%)$ had stage 2 pterygium (most of which were closer to the limbus than the pupil) while 4 eyes $(2.0 \%)$ had stage 3 pterygium. There was no subject with stage 4 pterygium. 
Table 1 Frequency Distribution of the 615 Motorcyclists by Duration of Riding in Years

\begin{tabular}{|l|l|l|}
\hline $\begin{array}{l}\text { Duration of } \\
\text { Riding (years) }\end{array}$ & Frequency & $\begin{array}{l}\text { Percentage } \\
(\%)\end{array}$ \\
\hline $0-5$ & 362 & 58.9 \\
$6-10$ & 167 & $27-2$ \\
$11-15$ & 55 & 8.9 \\
$16-20$ & 15 & 2.4 \\
$21-25$ & 11 & 1.8 \\
$26-30$ & 5 & 0.8 \\
\hline Total & 615 & 100.0 \\
\hline
\end{tabular}

Five hundred and five $(82.1 \%)$ of these riders, work for 10-12 hours in a day. Their riding period mostly spanned from 6 am to $6 \mathrm{pm}(84.9 \%)$ with a median resting time of 55.5 minutes.

Table 2 Association between Duration of Riding and Stage of Pterygium

\begin{tabular}{|l|l|l|l|l|}
\hline & \multicolumn{4}{|c|}{ Stage of Pterygium } \\
\hline $\begin{array}{l}\text { Riding } \\
\text { Years }\end{array}$ & Stage 1 & Stage 2 & Stage 3 & Total \\
\hline $0-5$ & $60(56.1 \%)$ & $61(64.2 \%)$ & $0(0 \%)$ & 121 \\
$6-10$ & $30(28.0 \%)$ & $17(17.9 \%)$ & $4(100 \%)$ & 51 \\
$11-15$ & $9(8.4 \%)$ & $8(8.4 \%)$ & $0(0 \%)$ & 17 \\
$16-20$ & $5(4.7 \%)$ & $4(4.2 \%)$ & $0(0 \%)$ & 9 \\
$21-25$ & $0(0 \%)$ & $5(5.3 \%)$ & $0(0 \%)$ & 5 \\
$26-30$ & $3(2.8 \%)$ & $0(0 \%)$ & $0(0 \%)$ & 3 \\
\hline Total & $107(100 \%)$ & $95(100 \%)$ & $4(100 \%)$ & $206(100 \%)$ \\
\hline \multicolumn{7}{|c|}{$X^{2}=23.540 . p=0.009$} \\
\hline
\end{tabular}

Table 3 Association between Age and Stages of Pterygium

\begin{tabular}{|l|l|l|l|l|}
\hline \multicolumn{4}{|c|}{ Stage of Pterygium } & \\
\hline $\begin{array}{l}\text { Age } \\
\text { (years) }\end{array}$ & Stage 1 & Stage 2 & Stage 3 & Total \\
\hline $11-20$ & $5(17.2 \%)$ & $23(79.3 \%)$ & $1(3.4 \%)$ & $29(100 \%)$ \\
$21-30$ & $27(56.3 \%)$ & $21(43.8 \%)$ & $0(0 \%)$ & $48(100 \%)$ \\
$31-40$ & $63(63 \%)$ & $35(35 \%)$ & $2(2 \%)$ & $100(100 \%)$ \\
$41-50$ & $6(28.6 \%)$ & $14(66.7 \%)$ & $1(4.8 \%)$ & $21(100 \%)$ \\
$51-60$ & $2(66.7 \%)$ & $1(33.3 \%)$ & $0(0 \%)$ & $3(100 \%)$ \\
$61-70$ & $4(80 \%)$ & $1(20 \%)$ & $0(0 \%)$ & $5(100 \%)$ \\
Total & $107(51.9 \%)$ & $95(46.1 \%)$ & $4(1.9 \%)$ & $206(100 \%)$ \\
\hline \multicolumn{7}{|c|}{$\mathrm{X}=27.064 . \mathrm{P}=0.003$}
\end{tabular}

$\mathrm{X}=27.064 . \mathrm{P}=0.003$
Table 4 Association between stage of pterygium, age and duration of riding

\begin{tabular}{|c|c|c|c|c|c|c|}
\hline & \multicolumn{2}{|c|}{$\begin{array}{ll}\text { Stage } & \text { of } \\
\text { Pterygium } & \\
\end{array}$} & \multirow[b]{2}{*}{ wald } & \multirow[b]{2}{*}{$\begin{array}{l}\text { Degree } \\
\text { of free- } \\
\text { free- } \\
\text { dom }\end{array}$} & \multirow[b]{2}{*}{$\begin{array}{l}\text { Signif- } \\
\text { icance }\end{array}$} & \multirow[b]{2}{*}{$\begin{array}{l}\text { Odds } \\
\text { ratio }\end{array}$} \\
\hline & $\begin{array}{l}\text { Stage } \\
1\end{array}$ & $\begin{array}{l}\text { Stages } \\
2 \text { and } \\
\text { above }\end{array}$ & & & & \\
\hline Age & 0.814 & 0.232 & $\begin{array}{l}12.3 \\
57\end{array}$ & 1 & 0.000 & 0.443 \\
\hline $\begin{array}{l}\text { Duration } \\
\text { of } \\
\text { Riding }\end{array}$ & 0.566 & 0.213 & $\begin{array}{l}7.08 \\
0\end{array}$ & 1 & 0.008 & 1.761 \\
\hline
\end{tabular}

The development of pterygium was not affected by the use of sunglasses to ride $(\mathrm{P}=0.072)$.

\section{DISCUSSION}

The prevalence of $19.3 \%$ for pterygium noted in this study is similar to the findings in other studies., 9,14 Ukponmwan et $\mathrm{al}^{9}$ in Benin city, Nigeria reported a $12.5 \%$ prevalence also among commercial motorcyclists and a lower $7.9 \%$ among indoor workers. Similarly, $11.8 \%$ prevalence of pterygium was noted among sawmill workers in south southern Nigeria. ${ }^{14}$ The motorcyclists are exposed to dust, wind, and UV light in the course of their duties, the principal risk factor for the sawmill industry workers ${ }^{14}$ is sawdust and this difference in risk factors in addition to the difference in sample size may account for the small difference noted.

While this study had 615 motorcyclists as subjects, Ukponmwan et $\mathrm{al}^{9}$ studied 144 motorcyclists. Bassey ${ }^{13}$ in Enugu state, Nigeria also found pterygium to be the commonest ocular condition in her study on taxi drivers. However, she reported a prevalence of $33.11 \%$ (198 drivers) and no case of pingueculum. This finding is surprising as the same risk factors predispose to pterygium and pingueculum. It is possible that Bassey ${ }^{14}$ in her study may have grouped cases of pingueculm as Stage 1 pterygium as pingueculum has

been reported to be a precursor of pterygium. ${ }^{15}$ These values though, support the finding by $\mathrm{Dake}^{2}$ that up to $22 \%$ prevalence for pterygium may be found in the tropics. Other studies ${ }^{1,10,16,17}$ in the temperate countries reported lower values $(5.9 \%-10.0 \%)$ than the present study. This is in keeping with the observation that pterygium is commoner in the warm, dry climates even though it has a worldwide distribution.

The severity of pterygium was graded only by its apical extent because the study was conducted outdoors at the motorcycle assembly units and there was no slit lamp available for detailed assessment. 
Three hundred and sixty two of the subjects (58.9\%) have been riding for five years or less (table 1). Of these, $56.1 \%$ had stage 1 pterygium. Similarly, as shown in Table 2, Stage 2 pterygium also occurred mostly among riders with riding experience within the 5 years bracket $(64.2 \%)$. This finding may be attributed to the fact that more than half $(58.9 \%)$ of the riders have been riding for 5 years or less.

In addition most of the riders $(71.8 \%)$ that have pterygium as shown in table 3 were within the $21-40$ years age bracket which happens to be within the 25 to 40 years age bracket that are more frequently affected by pterygium. ${ }^{18}$ The presence and severity of pterygium was noted to be significantly related to both the duration of riding $(\mathrm{P}=0.009)$ and age of the riders $(\mathrm{P}=$ 0.003) (see table 4).. This significance though had the odds in favour of duration of riding as being more likely to predispose the rider to developing pterygium than age probably because riding exposes the subjects to the risk factors of pterygium.

In contrast the result from Ukponmwan et al's ${ }^{9}$ study showed no significant difference between the mean duration of work between the motorcyclists with pterygium and pingueculum and those without any eye lesion. But they readily acknowledged the significant role of UV exposure and dust in the aetiology of these disorders. It has been shown that working in a mainly sandy environment by ages 20-29 years increases the risk of developing pterygium by almost11 times. ${ }^{6}$ The difference in the two studies may be related to the methodology and study design.

Generally, increasing age and exposure to sunlight and outdoor activities have been found to be significantly associated with occurrence of pterygium. The use of sun glasses did not significantly reduce the prevalence of pterygium $(\mathrm{P}=0.072)$. This may be a factor of the type of glasses used by the subjects. The subjects in this study are daily exposed to wind, dust and ultraviolet light, the three risk factors implicated in the aetiolo

gy of pterygium. Four hundred and fifty three (73.7\%) of the motorcyclists use sunglasses (not protective riding goggles) while riding to protect themselves against dust, wind, and sun glare among others. These sunglasses would be expected to reduce the effect of sunlight and therefore ultraviolet light exposure (if they were UV protected) to the eyes but will not seal out wind or dust as they are not ideal riding goggles.

Motorcyclists seen at the examination points had dusty faces, eyelids and eyelashes with or without sunglasses and their sunglasses were all inexpensive ones bought in the open market and therefore may not be UV protected. It is therefore not surprising that a high prevalence of pterygium was recorded and this was not significantly reduced by the use of sunglasses. Interestingly, Ukponmwan et $\mathrm{al}^{9}$ found that wearing hats/caps and sunglasses together protected the motorcyclists from developing pterygium.

\section{Limitations of the study}

A more detailed examination and grading of pterygium were not possible as there was no slit lamp available in the field. Thus, the true apex of the pterygium may have been missed in some cases of fleshy pterygium unlike the atrophic ones.

\section{CONCLUSION}

The increased prevalence of pterygium noted among these motorcyclists confirms the findings in other studies among outdoor workers. To reduce this prevalence, helmets with full-face shields or UV protected proper riding goggles where the helmets have no face shields are recommended as best protection for motorcyclists.

\section{REFERENCES}

1. Viso E, Gude F, Rodríguez-Ares MT. Prevalence of Pinguecula and Pterygium In A General Population In Spain. Eye (Lond). 2011;25(3):350-7.

2. Dake $\mathrm{Y}$, Mukae R, Soda $\mathrm{Y}$ et al. Immunohistochemical localization of collagen types I, II, III, and IV in Pterygium tissues. Acta Histochem (Jena) 1989; 87(1):71.

3. Nakaishi H, Yamamoto M, Ishida M, Someya I, Yamada Y. Pingueculae and Pterygia In Motorcycle Policemen. Ind Health. 1997;35(3):325-9.

4. Archila EA, Arenas MC. Etiopathology of Pinguecula and Pterygium. Cornea 1995;14:54344.

5. Saw SM, Tan D. Pterygium: prevalence, demography and risk factors. Ophthalmic Epidemiol.1999;6:219-228

6. Mackenzie F.D, Hirst IW, Battistutta D et al. Risk analysis in the development of Pterygium. Ophthalmology 1992; 99:1056.

7. Taylor HR, West SK, Rosenthal ES et al. Corneal changes associated with chronic UV irradiation. Arch Ophthalmol 1989; 107:1481.

8. Detels R, Dhir SP. Pterygium: A geographical study. Arch Ophthalmol 1967; 78:485.

9. Ukponmwan CU, Dawodu OA, Edema OF, Okojie O. Prevalence of pterygium and pingueculum among motorcyclists in Nigeria. East Afr Med J. 2007; 84(11):516-21.

10. Asokan R, Venkatasubbu RS, Velumuri L, Lingam V, George R. Prevalence and Associated Factors for Pterygium and Pinguecula in a South Indian 
population. Ophthalmic Physiol Opt. 2012; 32(1):39-44.

11. Kanski JJ. Disorders of the Conjunctiva. Clinical Ophthalmology. A Systematic Approach. Elsevier Science Limited 2002; pg. 83.

12. Araoye M. O. In Research Methodology with Statistics for health and Social Sciences. 1st ed. Ilorin: Nathadex publishers 2003: 119.

13. Bassey B.E. Ocular Status of Taxi-drivers in Enugu, Nigeria A dissertation submitted to the National Postgraduate Medical College in Part Fulfillment of the Requirements for the Fellowship of the College. 1993: 22-41.

14. Njinaka I, Uhumwangho OM, Edema OT, Dawodu OA, Omoti AE. A Comparison Study of Conjunctiva Disorders in Technical and Administrative Sawmill Workers in Nigeria. Malays J Med Sci. 2011;18(3): 43-48.
15. Raizada IN, Bhatnagar NK. Pinguecula and pterygium (a histopathological study). Indian J Ophthalmol 1976; 24:16-8.

16. Panchapakesan J, Hourihan F, Mitchell P. Prevalence of Pterygium and Pinguecula: The Blue Mountains Eye Study. Aust N Z J Ophthalmol. 1998; 26 Supp1 1:S2-5.

17. Gazzard G, Saw SM, Farook M, Koh D, Widjaja D, Chia SE, Hong CY, Tan DT. Pterygium in Indonesia: Prevalence, Severity and Risk Factors. $\mathrm{Br}$ J Ophthalmol. 2002; 86(12):1341-6.

18. Dinesh P. Surgical management of recurrent and progressive true pterygium in rural area. A dissertation submitted to Rajiv Ghandi University of Health Sciences, Karnataka, Bangalore in partial fulfilment for the requirements for the degree of master of surgery in Ophthalmology. 2012 